\title{
Magánbiztonsági tevékenység a tömeges bevándorlás okozta válsághelyzet szempontjából
}

\section{SZABÓ László András ${ }^{1}$}

\begin{abstract}
A cím egy olyan a tömeges bevándorlás okozta válsághelyzetet értelmez, amelyben a magánbiztonságnak, a vagyonvédelmi iparágnak nincs törvényben elöírt feladata. Menekültek nem tartózkodnak Magyarország területén, úgy mint azt 2015-ben tapasztaltuk. Ennek az állapotnak a jövőbeni lehetősége nem kizárható. Az állami szervezetek a határőrizetből eredő folyamatos létszámhiány miatt partnereket keresnek. Tanulmányomban a magánbiztonság feladatait dimenziók szerint elemzem, mindezt a tömeges bevándorlás okozta válsághelyzet szempontjából.
\end{abstract}

Kulcsszavak: magánbiztonság, tömeges bevándorlás, migráció, dimenziók, terhelés

\section{Bevezetés}

A cím egy olyan helyzetet értelmez, amely valójában nem létezik, és mégis van. Magyarországon tömeges bevándorlás okozta válsághelyzet van kihirdetve. Pillanatnyilag nincs a magánbiztonságnak a válsághelyzetben - az egyébként is törvényileg előírt - plusz feladata. Nincsenek illegális bevándorlók és menekültek olyan nagy számban Magyarország területén, mint azt 2015-ben tapasztaltuk. Akkor az a helyzet alapozta meg az Alaptörvény hatodik módosítását, sajnos az állapot újbóli kialakulásának a jövőbeni lehetősége nem kizárható. Az állami szervezetek a határőrizetből eredő folyamatos létszámhiány miatt partnereket keresnek. Ezek jelenleg a polgárőrség, az önkormányzati rendészet, és egy lehetséges újabb partner a tanulmányom tárgyát képező magánbiztonság. Hangsúlyozom, hogy a tanulmány születésekor még nincs az állami és a magánbiztonsági rendészeti szervezetek között átfogó együttmúködési megállapodás. Mégis az állami rendészeti szervezetekre nehezedő terhelés növekedése miatt a magánbiztonságra is átkerült a terheléselosztás. Ennek lényeges oka a vagyonvédelmi szektor egyre nagyobb térnyerése és az iparágban dolgozó szakemberek létszáma. Olyan nem nevesített feladatok, mint a terroristagyanús személyek felismerése vagy egy elvárt tevékenység a közbiztonság fenntartásának érdeke mind közérdek. Ezt csakis a képzéssel és a szakértelemmel kiegészített felkészítéssel lehetséges megoldani.

SZABÓ László András PhD-hallgató, NKE Közigazgatás-tudományi Doktori Iskola

László András SZABÓ PhD Student NKE Doctoral School of Public Administration Sciences

https://orcid.org/0000-0001-7957-0724, szabo.laszlo.andras@uni-nke.hu 
Az állami rendészeti szervezeteknek a déli határon az Ideiglenes Biztonsági Határzár őrzése és a járőrtevékenység okozta létszámelvonása más szervezetek bevonását teszi szükségessé. Ezek helyi szinten az önkormányzati rendészetek és a Polgárőr Szövetség helyi szervezetei. Meglátásom szerint a terhelés megoszlik a szervezetek között. Ez az úgynevezett komplementer rendészet. Vagyis az állami rendészeti tevékenység kiegészítéséhez partnerek és együttműködések kellenek. A tanulmány írásakor a magánbiztonsági iparág és az állami rendészet helyi együttmúködési szerződésekkel néhány önkormányzat tekintetében már rendelkezik. Viszont átfogó együttmúködési megállapodás partneri szerződéssel még nincs. Új magánbiztonsági törvény sincsen. Remélhetőleg a közeljövőben törvényalkotás útján változni fog a helyzet.

Ahhoz, hogy egy szervezet vagy szolgáltatás megjelenjen a piacon, alapvetően három fontos feltétel szükséges. Az egyik a jogi háttér, az állam megengedő szabályozó szerepe. A másik, hogy a tevékenység tárgya mindenki számára elérhető legyen. A harmadik, a biztonságra való igény napjainkban már alapérték. A migrációtól való félelem még inkább megalapozza ezt az igényt. A biztonság kialakításának, megteremtésének első számú letéteményese az állam és az állami rendészeti szervezetek.

Ezen feladatuknak egyedül nem képesek maradéktalanul eleget tenni, ehhez szükséges a nemzetközi együttmúködés, a társadalmi támogatás, az egyének hozzájárulása, illetve a tanulmányom tárgyát képező magánbiztonsági iparág. Továbbá, hogy legyen a piacon megfelelő nagyságú igény, vagyis fizetőképes kereslet. Tanulmányom egy pillanatfelvétel, amelyben a tömeges bevándorlás okozta válsághelyzet szempontjából értelmezem a magánbiztonsági tevékenység jelenét és lehetséges fejlesztési irányait. A vizsgálat részét képezik a társadalmi, közösségi, egyéni, gazdasági dimenziók is. Nagyon fontos a megértés és megismerés szempontjából elemezni azt a társadalmi gazdasági és politikai környezetet, amelyben a magánbiztonsági szolgáltatások létrejönnek. A magánbiztonság közkapcsolati hálóját. Ma a kockázatalapú értelmezésú és érvelésű szempontrendszer, vagyis a menedzserszemlélet tekinthető uralkodónak a területen.

A kockázatelemzés részben a katonai részben a polgári és meglepő módon a biztosítók gyakorlatából került át először a rendőrség és az igazságszolgáltatás gyakorlatába, majd a magánbiztonság is elkezdte alkalmazni a szempontrendszereket a tevékenysége során felmerülő kockázati helyzetek, cselekmények, helyek és személyek beazonosítása és valamilyen mérőszám általi kockázati osztályba sorolása miatt. Globalizált világunkban a kockázat fogalma Anthony Giddens globalizációkutató szociológus megfogalmazásában: „A kockázat olyan veszélyekkel kapcsolódik, amelyeket a jövő lehetőségeinek összefüggésében értékelünk. Egy társadalmon belül a kockázati szemléletet akkor kezdik el általánosan alkalmazni, ha a társadalom jövőorientált, ha a jövőt pontosan olyan területnek látja, amelyet le kell győzni vagy meg kell hódítani. A kockázat olyan társadalmat feltételez, amelyik aktívan igyekszik múltjától elszakadni, ami tulajdonképpen a modern ipari civilizáció alapvető vonása."2 A biztonság és kockázat értelmezése lehet ellentétes vagy kiegészítheti egymást. Egymásra hat, szinergiában dolgozik és min-

\footnotetext{
Giddens (2000) 33.
} 
dennapjainkat áthatja. Fontos kiemelni még egy kifejezést, amely áthatja napjainkat: ez a morális pánik. David Garland szociológus így fogalmazza meg „A morális pánik megfelelő értékelése a kockázattársadalomban különleges fontossággal bír, hiszen főként az objektív kockázatot fókuszba helyező rizikótársadalom-elemzés így összekapcsolható a szubjektív kockázat morális pánikban való megnyilvánulásával, azaz az objektív biztonság és szubjektív biztonságérzettel."3

A magánbiztonság egyfelől rendészeti eszközök és technikák, másfelől biztonságtechnikai berendezések és rendszerek, harmadrészt adatkezelés és adatok tárolását végző szervezetrendszernek tekinthető. Illetve mindezeknek a társadalmi objektív és szubjektív percepciója. Ezzel elérkeztünk a vizsgálandó kérdéshez. Milyen feladatai vannak, lehetnek a magánbiztonságnak a tömeges bevándorlás okozta válsághelyzetben Magyarországon? Michel Foucault szociológus szerint „nincsen, olyan nézőpont a társadalomban, amely ne lenne a társadalmi helyzetektől meghatározott”. Felmerül a kérdés, hogy ha valójában nincs a magánbiztonságnak jelenleg hivatalos, törvényi plusz feladata a tömeges bevándorlás okozta válsághelyzetben, akkor hogy lehet, hogy mégis van. A tanulmány első részében a tömeges bevándorlás válsághelyzet fogalmát értelmezem, majd a migráció fogalmát és azon típusait tekintem át, amelyek a tanulmány szempontjából relevánsak. Ezután a tömeges bevándorlás okozta válsághelyzet szempontjából a magánbiztonság lehetséges feladatait dimenziók szerint elemzem.

\section{A tömeges bevándorlás okozta válsághelyzet fogalma}

Orbán Balázs megfogalmazásában: „Emberek meghatározott földrajzi területre történő magas intenzitású, nagy tömegű, kontrollálatlan úgynevezett irreguláris migrációs mozgással bekövetkező beáramlása. A tömeges bevándorlás okozta válsághelyzet következtében a beáramlással érintett területen megnő a politikai, gazdasági, társadalmi, kulturális feszültség, és jellemzően jelentős biztonságpolitikai kockázatok merülnek fel." 4

A tömeges bevándorlás okozta válsághelyzet Magyarország egész területére történő elrendeléséről: ${ }^{5}$ a menedékjogról szóló 2007. évi LXXX. törvény (a továbbiakban: menedékjogról szóló törvény) 80/A. § (2) bekezdése kimondja, hogy az országos rendőrfőkapitány és a menekültügyi hatóság vezetőjének kezdeményezésére, az idegenrendészetért és a menekültügyért felelős miniszter javaslatára a kormányrendeletben rendelheti el a tömeges bevándorlás okozta válsághelyzetet. A tömeges bevándorlás okozta válsághelyzet elrendelhető Magyarország meghatározott területére vagy egész területére. A kormány a tömeges bevándorlás okozta válsághelyzet Magyarország egész területére történő elrendeléséről, valamint a válsághelyzet elrendelésével, fennállásával és megszüntetésével összefüggő szabályokról szóló 41/2016. (III. 9.) Korm.

\footnotetext{
Garland (2003) 48-86.

Orbán (2019) 13-18.

41/2016. (III. 9.) Korm. rendelet a tömeges bevándorlás okozta válsághelyzet Magyarország egész területére történő elrendeléséről, valamint a válsághelyzet elrendelésével, fennállásával és megszüntetésével összefüggő szabályokról.
} 
rendelettel - 2016. március 9-ei hatálybalépéssel - elrendelte Magyarország egész területére a tömeges bevándorlás okozta válsághelyzetet.

A fogalomhoz hozzátartozik az érintett területen, Magyarország területén a közrend és közbiztonság fenntartását biztosító szervezetek főképp a rendőrség feladata megnő, és ezzel együtt a létszámterheltsége is emelkedik.

\section{A migráció a tanulmány szempontjából fontos fogalmi kerete}

Mielőtt a migráció fogalmát ismertetném, meg kell jegyezzem, hogy nagyon nehéz a jelenség tekintetében a fogalomalkotás. Szerteágazó sok összetevőjü és hatású jelenségről van szó. A következő fogalom egy általam megfogalmazott és a tanulmányban használt a jelenséget leíró fogalom. A migráció fogalma: egy olyan folyamat, amelyben a személyek tartózkodási helyet, illetve társadalmat váltanak oly módon, hogy ez a váltás lehet átmeneti vagy állandó.

A népességmozgás tipikus esete az évszázadok óta folyó munkaerő-migráció. Emellett a munkavállalási szándék mellett számos tényező növeli a migrációs hajlandóságot. Ugyancsak évszázados, talán inkább évezredes múltja van a vallási, etnikai, politikai üldözöttek migrációjának. Az utóbbi időben egyre inkább megfigyelhető a migrációs motivációkban a politikai és gazdasági tényezők keveredése.

\section{Nemzetközi migráció}

Nincs rá meghatározott egyértelmű definíció. Megfogalmazásomban minden, ami két vagy több szuverén állam, térség vagy egymástól elkülönült földrajzi terület közötti bármely okból és célból történő migrációt eredményez.

\section{A nemzetközi migráció jellemzői}

Közigazgatási határok átlépése: schengeni övezet esetén ezek formálisak. Az Európai Unió hármas alapgondolata markánsan megjelenik. Áruk, szolgáltatások és személyek szabad áramlása.

Huzamos időtartamra szól: ha munkavállalásról, házasságról beszélünk, ez egyértelmű. A válság okozta migrációnál nagy kérdés, hogy meddig kell ellátni a menekülteket, bevándorlókat. És hogy mekkora a hajlandóság a hazájukba való visszatérésre.

Társadalmi, kulturális és nyelvi váltás a nemzetközi migráció esetében: általában nem demokratikus és gazdaságilag fejletlenebb országból, területről érkeznek a migránsok. Sokszor háborúból menekülve, egy közigazgatás és meghatározott jogrend nélküli országból. Egy teljesen új kulturális területre való érkezés komoly kihívás elé állítja a migránsok identitását. Előkerül a régi vita: asszimiláció - vagyis a teljes identitás, nyelv, kultúra feladása - vagy integráció - csak annyit ad fel a bevándorló az identitásából, amennyi a túléléshez, a munkavállaláshoz elengedhetetlen. 
Ezt szemléletesen Koller Boglárka identitásháló-elmélete mutatja meg. Ezt úgy lehet elképzelni, mint egy olyan hálót, amelynek minden egyes pontján egy-egy karácsonyfaizzó van, amely adott esetben ég, máskor nem. Az is előfordulhat, hogy egy izzó erősen vagy halványabban ég, illetve hogy sok vagy kevesebb izzó ég egyszerre. Az egyén élete során időről időre változtatja kötődéseit, azok fontossági sorrendjét. $\mathrm{Az}$ identitáselemek viszonya nem hierarchikus, hanem mellérendelt. ${ }^{6}$ Ezt a migráció tekintetében úgy lehet értelmezni, hogy bizonyos „karácsonyfaizzókat” az egyén lecserél, hogy minél jobban integrálódni tudjon. Ezen lecserélt égők száma annyi, amennyi feltétlenül szükséges az új helyzethez való alkalmazkodáshoz. Ennek ellenpontozásához az egyén identitásának legfontosabb égői erősebben égnek. Ha ez túl erős, az már az ellenállás a kulturális befelé fordulás jele.

\section{A nemzetközi migráns fogalma}

Nehéz a statisztikai elemzése. Az adatfelvételt megnehezíti, hogy az önbevalláson alapuló minták az egyén szubjektív megítélésétől függnek, valamint hogy egy migráns több céllal is érkezhet. Úgymint egyszerre menekült és gazdasági bevándorló, vagy tanulni jön, párhuzamosan munkát vállal, de ilyen lehet a családegyesítés is. Nagy a látencia, és hiányzik az egységes definíció.

\section{Nemzetközi migráció típusai}

Rövid távú tartózkodó - Úgy is lehet értelmezni, mint határozott idejû vagy átmeneti tartózkodás. Ebben az esetben a hazába való visszatérés valószínű. Magában foglalja a szezonális (szolgáltatási ágazatokhoz kapcsolódó) vándorlást, az ingázó (államhatárok menti munkaerőmozgásból eredő vándorlást), és az időbeni ritmus nélküli, szabadidős hivatás- vagy bevásárlóturizmust. ${ }^{7}$

Tranzitvándorlás - Azokat az országokat és területeket értem ide, amelyek nem célországok, de át kell rajtuk kelni. Ezt láttuk a hazánkat ért tömeges migrációnál 2015-ben.

Migráns - A lexikon megfogalmazásában: „idegen állam lakosainak, polgárainak az állam területére lépése oly szándékkal, hogy állandóan ott éljenek, maguknak új otthont alapítsanak". ${ }^{8}$

Bevándorló - A bevándorló jogi kategória, amelyet a magyar jog így értelmez. „Az a bevándorolt jogállású külföldi állampolgár, aki az illetékes magyar hatóság által kiadott érvényes bevándorlási engedéllyel életvitel-szerűen él Magyarországon, és az ország területén bejelentett lakóhelye van." ${ }^{9}$ Ezt az ENSZ nemzetközi migrációval foglalkozó szervezetei állásfoglalásukban így határozták meg: „Az a személy, aki a jelenlegi lakóhelyéhez

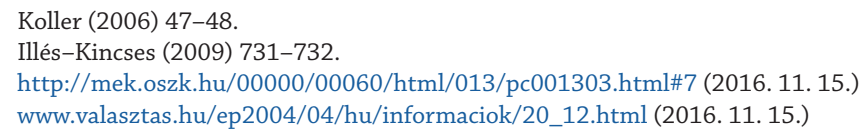


képest egy másik országba költözik legalább egyéves időtartamra, azért, hogy a célország legyen az új lakóhelye." ${ }^{10}$

Menekült - A menekültállapotot a törvények a következőképpen határozzák meg. „Magyarország menekültként ismeri el azt a külföldit, akinek az esetében az Alaptörvény XIV. cikk (3) bekezdésében meghatározott feltételek fennállnak."11 az Alaptörvény alapján: „Magyarország - ha sem származási országuk, sem más ország nem nyújt védelmet - kérelemre menedékjogot biztosít azoknak a nem magyar állampolgároknak, akiket hazájukban vagy a szokásos tartózkodási helyük szerinti országban faji, nemzeti hovatartozásuk, meghatározott társadalmi csoporthoz tartozásuk, vallási, illetve politikai meggyőződésük miatt üldöznek, vagy az üldöztetéstől való félelmük megalapozott."12

További meghatározás a Bevándorlási és Menekültügyi Hivatal honlapja szerint: „Az a személy lehet menekült, aki faji, illetőleg vallási okok, nemzetiségi vagy meghatározott társadalmi csoporthoz tartozása, avagy politikai meggyőződése miatt hazájában üldöztetést szenvedett el, vagy ilyen üldöztetéstől megalapozottan fél, jelenleg Magyarország területén tartózkodik és menekültstátusz iránti kérelmet terjesztett elő. A család egységének biztosítása érdekében - ha elismerést kizáró ok nem áll fenn - kérelemre menekültként kerül elismerésre a menekült családtagja (házastársa, ha a családi kapcsolat már Magyarországra érkezésüket megelőzően fennállt; kiskorú gyermeke, kiskorú gyermek esetén szülője), valamint a menekült Magyarországon született gyermeke. A menekültstátusz a magyar állampolgárság megszerzéséig, valamint a menekültstátusz visszavonásig illeti meg a menekültként elismert személyt. A menekültstátuszt a menekültügyi hatóság hivatalból legalább háromévente felülvizsgálni köteles." ${ }^{13}$

Illegális - Nincs egységes meghatározás az illegális migrációra. Általában a legális ellentét párjaként lehet értelmezni. Vagyis „ami nem legális, az illegális.” logikai levezetés használatos. „Az illegális migránsok külföldiek, legális jogi státusz nélkül. Közös jellemzőjük, hogy nincs semmilyen érvényes törvényes tartózkodási jogosítványuk ott létezni, ahol vannak.

A hiányzó jogi státusz messzemenően meghatározza ezeknek az embereknek az egész életvezetését. Az ENSZ hivatalos terminusai - irreguláris, nem ellenőrzött, vagy nem dokumentált migráció - nem felelnek meg igazán valós élethelyzetüknek. Az illegalitás jelenségének ugyanis fő jellemzője, hogy az érintett személyek megkísérlik kivonni magukat az állami felfedezés elől, és ezzel természetesen a hivatali-statisztikai nyilvántartás elől is."14

(Ir)reguláris migráns - A reguláris migráns a - legális kifejezéssel párhuzamosan - lényegében ez esetben is azt jelenti, hogy a külföldi személy a fogadó állam szabályait figyelembe veszi, míg irreguláris az a migráns, aki külföldiként érvényes jogi státusz nél-

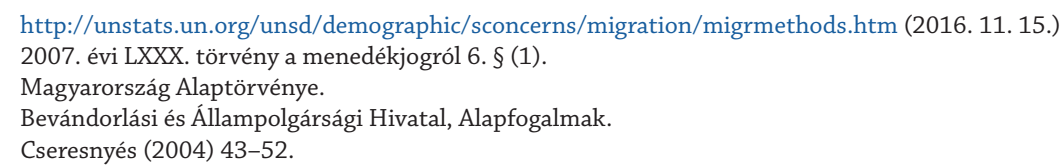


kül tartózkodik egy állam területén. A fogalomváltozás mögött az az emberi gondolat húzódik meg, hogy egy beutazás vagy tartózkodás mint emberi magatartás lehet jogellenes, addig annak alanya (vagy elkövetője) nem. További okként kell foglalkozni azzal a körülménnyel is, hogy minden legális beutazásból lehet jogellenes tartózkodás. ${ }^{15}$

Egyéni vagy többes - A migráció, mint a fentiekben már kifejtettem, egyéni szubjektív döntésen alapul. A vándorlás az emberhez kötődő és alapvetően csoportos tevékenység. A történelem változásával, a külső fenyegetettségeknek való kitettség csökkenésével, illetve a jogok (polgári, politikai jogok) megjelenésével egyre inkább háttérbe szorult a csoportos, akár egész népet, népességet érintő vándorlás az egyénivel szemben.

Tömeges migráció - A tömeges migráció jelensége, és annak kezelése a rendészeti szervezetek számára az egyik legnagyobb kihívás. A tömeges migráció kialakulása mögött meglévő sajnálatos tényezők révén is alakulhatnak ki olyan fogalmak, mint „invázió”, „bomba” vagy „hullám”, amelyek - Nils Muiznieks szavaival élve - természeti katasztrófák vagy fegyveres konfliktusok tulajdonságaival ruházzák fel magát a jelenséget. ${ }^{16}$

\section{A közbiztonság rendszertípusai}

A magánbiztonsági tevékenységet a közbiztonságból vezetem le. Nem lehet önmagában a többi rendszertípustól elkülönítve értelmezni.

Finszter Géza szerint a közbiztonsági rendszer a következő rendszertípusokból áll: ${ }^{17}$

- a rendészeti rendszer (rendőrség, önkormányzati rendészet/közterületfelügyelet);

- a magánbiztonsági rendszer és magánbiztonsági szolgáltatások;

- a civil önvédelmi rendszer (polgárőrség).

Finszter Géza másfelől, a működés irányából közelíti meg a kérdést. „A rendészet a civil közigazgatás integráns része, ilyen minőségében teljes egészében a jog uralma alatt áll." Ami a hatalmi ágak megosztásának elvét illeti, a közbiztonsági rendészet a végrehajtó hatalom irányításával müködik, a bűnügyi rendészet pedig az igazságszolgáltatás előkészítője, a büntető hatalom érvényesítésének eszköze. Megállapítható tehát, hogy hiába is keresnénk, a törvényekben nem található az, hogy magánbiztonság.

A fogalmat megtöltő tevékenység szabályozását a hatályos jogszabály a személyés vagyonvédelmi, valamint a magánnyomozói tevékenység szabályairól szóló 2005. évi CXXXIII törvény így definiálja: „[A] közrend, a közbiztonság javítása, s ezek részeként a személy- és vagyonvédelem, a bűnmegelőzés hatékonyságának fokozása érdekében erősítse a vállalkozás keretében végzett személy- és vagyonvédelmi, valamint a magánnyomozói szolgáltatás törvényességét, és további garanciát nyújtson a társadalom számára

\footnotetext{
Windt (2008) 52.

Hautzinger-Hegedűs-Klenner (2014) 12.

17 Finszter (2013) 87.
} 
az e szolgáltatásokat igénybe vevők, illetve az e szolgáltatások gyakorlása során érintettek személyhez füződő jogai, vagyoni érdekei sérthetetlenségére irányuló igényeinek érvényesítéséhez."18

A magánbiztonság Kacziba Antal megfogalmazásában: „olyan kívánatos jogállapot, amelyben a személy és a jogi személy a magánjogban kifejeződő szabadságjogainak, gazdasági, szociális és kulturális jogainak egyenjogúsága, valamint jogos érdekeinek érvényesülése szavatolt". ${ }^{19}$

\section{A magánbiztonság múködésének dimenziók szerinti elemzése}

Ahhoz, hogy a bevezetésben felvetett kérdést megválaszoljuk, egy többdimenziójú elemzést használok a tevékenység és a magánbiztonság helyzetének az elemzésére. Ez a tanulmány módszertana is egyben. A dimenziók szerinti elemzést azért tartom megfelelőnek, mert ebben a formában az egyes részek kiegészítik és áthatják egymást. Komplex rendszerré egészítve ki az egyes dimenziókat. Ez a szempontrendszer egy elemző módszert jelent.

Irk Ferenc kriminológus, ezt nem az elemzésem tárgyára, vagyis a magánbiztonságra alkotta meg, hanem általában kockázati (rizikó) jelenségek elemzésére, így azt, újra gondoltam, átformáltam.

Az elemzés tizenegy dimenzió mentén történő értelmezése, megtartva az eredeti szemléletet az úgynevezett „objektív szemüveg”, vagyis az objektív értékelés módszerét. ${ }^{20}$ A szempontrendszer bár nem a magánbiztonságra lett kialakítva, nagyon jól adaptálható. Tehát egy egzakt viszonyítási rendszer adott, amely dimenziók mentén értelmezi a magánbiztonság lehetséges tevékenységeit a tömeges bevándorlás okozta válsághelyzetben. A dimenziók tárgyalásánál egy-egy jól definiált mondattal konkrétan és egyértelmúen utalok az adott magánbiztonsági dimenzió és azon belül is a feladatrendszer tömeges bevándorlással kapcsolatos aspektusaira.

\section{Tudományos és képzési dimenzió}

Ez egy kétoldalú és kétarcú helyzet. Az egyik oldal a biztonságtechnikai eszközök, megfigyelő kamerák, veszélyjelzők, beléptetőrendszerek és az egyre fejlettebb drónok. A hihetetlenül magas technikai innováció. A másik oldal a személyes kapcsolat, a benne dolgozó szakemberek szakértelme, képzettsége és képességei. Az eljárásmód, ahogy a polgárokkal a megrendelőkkel a szolgáltatást igénylőkkel bánnak. Vagyis a tevékenységben megjelenő humánum. Hiszen a magánbiztonság-szakemberek emberekkel foglalkoznak, a polgárokkal sokszor azok legrosszabb helyzetében, állapotában mint bű́ncselekmények áldozataként találkozik. Ilyenkor fontos a humánum, a helyzetet tovább nem rontó, azt szakértelemmel megtöltő cselekvése a magánbiztonságnak.

\footnotetext{
2005. évi CXXXIII. törvény a személy- és vagyonvédelmi, valamint a magánnyomozói tevékenység szabályairól.

Kacziba (2013) 33-34.

20 Irk (2012) 307-308.
} 
A tudományos és képzési dimenzió feladata a tömeges bevándorlással kapcsolatban, annak jelenségszintű megismerése, és a szakemberek felé tudományos alapon kidolgozott ajánlások készítése. Így a magánbiztonság komplex rendszerén belül a lehetséges fejlesztési irány meghatározása. Az eredmények a továbbképzésekbe és az egyetemi képzésekbe történő beépítése, új képzési szakirányok kijelölése.

\section{Hatalmi dimenzió}

Több vagy kevesebb állam, túl- vagy alulszabályozás - örök dilemma. Minden szervezet akkor müködik megfelelően, ha a feladatok és hatáskörök kellően szabályozottak és elválasztottak egymástól. Az állam legfőbb feladata a megfelelő törvényi háttér megteremtése lett. Ez érvényes a magánbiztonsági tevékenység megfelelő szintû állami szabályozására a civil kontroll részvételére a szakmai szervezetek ellenőrzésére és az átlátható működésre, gazdálkodásra, vagyis az inkább „több állam”-koncepciója.

A hatalmi dimenzió feladata a tömeges bevándorlással kapcsolatban a magánbiztonság számára a válsághelyzet idejére külön jogosultságok megadása. Ilyen a biztonsági őr közfeladatot ellátó személynek minősítése, és a fokozott ellenőrzés során végrehajtott személy- és adatellenőrzések. Ezen jogosultságok a rendészeti szervezetek terheltségét segítenek csökkenteni. A jogosultságok célhoz és időhöz kötöttek. Az eljárások törvényességét a rendőrség ellenőrzi.

\section{Nemzetközi dimenzió}

Bármerre megyünk a világon a repülőterektől a plázákig mindenhol a magánbiztonság szakembereivel találkozunk. Ott vannak a beléptetésnél, a felszállásnál, a kormányhivatalokban és a kórházak területén. Ma már nincs a világnak olyan szeglete, eldugott része, ahol ne lennének jelen a magánbiztonsági vállalkozások. A globalizáció az egyenlőtlenségek növekedése által a társadalmi dezorganizáció és az erőszak melegágya. ${ }^{21}$ Ahogy Anthony Giddens szociológus értelmezi a globalizáció: „1. a világkapitalista gazdaság, 2. a munka nemzetközivé válása, 3. a nemzetállami rendszer fennmaradása, 4. egy a világot behálózó katonai rendszer". ${ }^{22}$ Ahova megy a tőke, oda megy annak védelmére a katonaság. Modern demokratikus nemzetállamoknál ez nem müködik. Így a magánbiztonság működését kell megteremteni, mert a tőke paranoiás, retteg mindentől.

A nemzetközi dimenzió feladata a tömeges bevándorlással kapcsolatban a nemzetközi szabályozás és a jó gyakorlatok vizsgálata. A magánbiztonság határokon átnyúló tevékenységének az adott állami szervezetekkel történő összehangolása és együttműködése.

\footnotetext{
Gillespie (2006) 24-44.

22 Giddens (1990) 71. Vö.: Gillespie (2006) 28.
} 


\section{Kulturális dimenzió}

A magánbiztonság a kultúra része, ez ma már tény. Magántulajdon van, vagyis a magánbiztonsági tevékenységre igény van. Egy jól menő vállalkozó testőr nélkül, pontosabban személyi titkár nélkül már el sem képzelhető. Az egyenruhás biztonsági őrök a repülőtereken a pénzszállításnál, a bevásárló áruházak kasszasoránál, a mozik bejáratánál vagy a bármilyen bolt, szórakozóhely előtt a mindennapi kép részei. Beépültek a köztudatba a környezeti kultúra részei lettek. Ez már társadalmi és kulturálisan beágyazódott értékrendszer. Európa, sőt a világ bármely részén járunk, már észre se vesszük ezt a láthatatlan sereget. Csak ha figyelünk rájuk. A magánbiztonság múködése már nemzeti érdek és érték lett. A magánbiztonság is ennek a kultúrának része és fenntartója.

A kulturális dimenzió feladata a tömeges bevándorlással kapcsolatban a magánbiztonsági tevékenység és a benne dolgozó szakemberek kommunikációja, megjelenésével az állampolgárok biztonságérzetének növelése.

\section{Társadalmi dimenzió}

Az elvárás, amely egy jól múködő államban létezik, ami a társadalom és a piac, vagyis a megrendelői oldalról képződik le. Az állami elvárást a törvényi részben elemeztem, csakúgy mint a társadalmit a kultúra részben. De mi van a társadalom azon részével, a tömeggel, aki csak szemlélője a történéseknek. Gönczöl Katalin kriminológus ezt így fogalmazza meg: „A piaci társadalomban kifejlődnek azok a szolgáltatások, beruházási lehetőségek, amelyek igénybevétele, illetőleg megvásárlása esetén a kockázat és a veszélyérzet egyaránt csökkenthető. E kereskedelmi és szolgáltató tevékenység országos hálózata az elsődleges megelőzés infrastruktúrájába tartozik. A megelőzési stratégia és taktika múködéséhez elengedhetetlen a tényleges kockázatra vonatkozó felvilágosítás, a hiteles információ szolgáltatása, annak a folyamatnak a tudatos elősegítésére, amelyben az adott kis- és nagyközösség tagjai megismerhetik az áldozattá és a bủnelkövetővé válás esélyeit, következményeit, elkerülésének módjait és az ehhez rendelkezésre álló intézményes segítség eszközeit." ${ }^{23}$

A társadalmi dimenzió feladata a tömeges bevándorlással kapcsolatban a már Magyarországon lévő menekültek és bevándorlók társadalmi integrálásának segítése. Az esetleges konfliktusok megfelelő kezelése és az előítéletek csökkentése a befogadók és a befogadottak között.

\section{Médiadimenzió}

Ez a magánbiztonsági tevékenység megjelenése a médiában. Egyáltalán megjelenik a hírekben az írott és elektronikus médiákban a magánbiztonság. Jellemzően ritkán,

23 Gönczöl-Kerezsi-Korinek (2013) 19. 
csak bűncselekményhez kapcsolva. A magánbiztonság, illetve a biztonsági őrök megjelenése a hírekben sokszor csak a három „b” szempontjából a bulvár, botrány és bűnözés hármasában történik. Bulvárhír, botrány például, ha lopott, megütött valakit a biztonsági őr, kidobtak valakit, lehetőleg híres embert valahonnan. Vagy egy bűncselekmény kapcsán, ahol az őr az áldozat volt, bankban lövöldöztek, illetve pénzszállítót raboltak ki. Nem baj, ha egyébként nem jelenik meg. Akkor dolgozik jól, ha minél kevesebbet hallunk róla mert akkor múködik az a fajta elrettentést, amit a társadalom elvár tőlük.

A médiadimenzió feladata a tömeges bevándorlással kapcsolatban a médián keresztül is a törvényesség és szakszerűség megjelenése a nyilatkozatokban.

\section{Közügyi, közérdekú dimenzió}

A társadalmi diskurzusban sokszor úgy jelenik meg a biztonság, mintha az egy privilegizált egyenlők az egyenlőbbek között vagyonnal rendelkező kör kisajátított biztonsága lenne. Nehéz ettől elvonatkoztatni. A magánbiztonság a benne dolgozóknak sokszor csak megélhetés, és általában egy alacsony presztízsű szakma. Ennek változnia kell. Mert megjelenik a szakmai közbeszédbe és átszivárog a társadalmi diskurzusba is. Christian László így látja „a közügy és a magánügy közötti határvonal egyre halványul, elmosódik relatívvá válik és szinte naponta változik. Így van ez a közbiztonság és a magánbiztonság határaival is". ${ }^{24}$

A közügyi, közérdekű dimenzió feladata a tömeges bevándorlással kapcsolatban a biztonság mint közös termék szolgáltatása az állam a társadalom a megrendelői kör és az egész társadalom felé. Együttműködés a közös ügy kialakítása során.

\section{Magánterület, közterület dimenzió}

A korábbiakhoz képest jelentősen kibővült - és nagyságrendjét tekintve is növekszik - a vagyonőrzők szolgáltatásait igénylők köre, de magának a szolgáltatásnak a köre is. Egy állami vagy önkormányzati intézmény (közhivatal, kórház, múzeum, iskola, és még sorolhatnánk) számára nyújtott biztonságszolgáltatás egyben közérdekű, a közbiztonságot közvetlenül is szolgáló tevékenység. A tömegközlekedési eszközökön, állomásaikon teljesített szolgálat a közlekedési vállalat dolgozóinak, eszközeinek védelme mellett az utasok biztonságát is szolgálja, s így a közfeladat jegyeit viseli magán. Egyes önkormányzatok már a közterület rendjének biztosításában is igénybe veszik a biztonsági szolgálatok közremúködését (például egy park mint objektum berendezési tárgyainak, szobrainak rongálás elleni védelmére, az odalátogatók biztonságának megóvására).

A magánterület, közterület dimenzió feladata a tömeges bevándorlással kapcsolatban a jogsértő tevékenységek mindkét területen történő megakadályozása, megszüntetése.

24 Christian (2014) 19. 
A magántér és a köztér szervezeteivel az együttmúködés kialakítása. A két terület adott esetben történő átjárhatósága.

\section{Biztonsági, rendészeti dimenzió}

A biztonság a nyugodt, veszélyektől mentes élet napjainkra érték lett. Ez alapján választunk lakóhelyet, munkahelyet a gyermekünknek óvodát és iskolát. Még a sportolásnál a szabadidő vagy a turizmus tekintetében is fontos szemponttá vált a biztonság. Finszter Géza szerint a biztonság egyfelől a rendészeti igazgatás által nyújtott hatósági szolgáltatás, másfelől pedig a piacon - a vagyonvédelmi vállalkozások által - kínált és megvásárolható termék. Egyesek hangoztatják a „biztonsági ipar” szükségszerűségét a magántulajdonon alapuló piacgazdaságban, amikor a magánterek a közterületek rovására egyre terebélyesednek.

A biztonsági, rendészeti dimenzió feladata a tömeges bevándorlással kapcsolatban a szolgáltatás nyújtása azok számára is, akik nem állnak üzleti kapcsolatban a magánbiztonsággal, viszont adott esetben, mint a tömeges bevándorlás okozta válsághelyzet esetén, szükségük van rá.

\section{Gazdasági dimenzió}

A magánbiztonság két elvárásrendszer közé van beszorítva. Az állami és a piaci keresleti. Ezért a működésének hatékonysága vagy társadalmi hasznossága egyrészt a tevékenység szakmai sikerét alapul véve nem egzakt módon, vagyis bevételben mérhető, hanem a társadalmi megbecsülésben jelenik meg. Hiszen a bűnalkalmak csökkenését, a sikertelen bűncselekményeket nehéz mérni, nagy a látencia. Történhet a tevékenység elején egy egyszeri csökkenés, aztán stagnálás. Másrészt a piaci részesedést, a bevételt, a kitermelt profitot pontosan és kimutathatóan méri egy vállalkozás. Ez a magánbiztonsági vállalkozásokra is igaz: munkahelyeket teremt, adót fizet, új képzéseket támogat.

A gazdasági dimenziós feladata a tömeges bevándorlással kapcsolatban a kutatásfejlesztésre szánt pénzekből a jelenséghez tartozó eljárásokba, képzésekbe és biztonsági eszközökbe történő innováció.

\section{Kriminálpolitikai dimenzió}

A magánbiztonság a biztonság konstruálásában megfelelően részt vesz, munkahelyeket teremt, adót fizet. A partnerség kettős. A társadalmi nézőpont egyenlő azzal a már kifejtett elvárással, hogy legyen egy szakmailag magas szinten álló, de megvásárolható szolgáltatást nyújtó szervezet, amely az állampolgárok szubjektív és objektív biztonsági igényének eleget tud tenni. De sajnos nem ilyen szép a helyzet. Ahogy láttuk egy társadalom védekezése vagy befogadóképessége és az aktuális állami kriminálpolitika hatása és a büntetőpolitika determinálja azon szolgáltatások elérhetőségének anyagi vonzatát, vagyis a piaci árat, amit csak a vagyonosabb réteg tud megfizetni. A James 
Q. Wilson és George L. Kelling „betört ablakok elméletével”, ${ }^{25}$ és az ebből kialakuló zéró tolerancia rendészeti stratégia vagyis a normasértő, deviáns jelenségek megjelenése ezzel együtt a bünözéstől való félelem növekedése a magánbiztonsági piacra is hatással van. Ha nő a félelem, az átlag polgárok először a mechanikus és elektronikus védelmi eszközök felé fordulnak, majd a komolyabb biztonságtechnikai eszközöket, a GPS-rendszereket és az ezt kiegészítő élőerős őrzést választják. A magánbiztonság rendészeti eszközrendszere gyengébb, mint az állami szervezeteké a biztonságtechnika magasabb szintű az adatkezelés GDPR megfelelően szabályozott. Tevékenysége nem hasonlít, bár jellegében mutat bizonyos rokon vonásokat a hagyományos rendészeti szervezetek metodikájával. A legfontosabb a megrendelőtől való függés.

A kriminálpolitikai dimenziós feladata a tömeges bevándorlással kapcsolatban a jelenség kezelésének céljából a szervezeti keretek kialakítása. A rendészeti és a lehetséges komplementer szervezetek, mint a magánbiztonság számára szakmai eszközök ajánlása.

\section{Konklúzió}

Európában változik a biztonság, ami összefüggésben van a bűnözés tendenciájával a tömeges bevándorlással és a megjelenő terrorizmussal. Fontos leszögezni, hogy a migráció és a terrorizmus nem ok-okozati összefüggés, hanem kockázati tényező. A magánbiztonság helyzete, feladata is változik a komplementerrendészet egyre nagyobb teret kap. A változás folyamatos, mert napjainkban a biztonságot veszélyeztetó jelenségek is újra megfogalmazódnak, változnak. így a migráció jelensége újraírja gondolkodásunkat, félelmeket és konfliktusokat létrehozva. Magyarországon a szabályozás ebben a tekintetben megfelelő volt mostanáig. A témával foglalkozó kutatók általában a nyugaton múködő magánbiztonsági cégeket vizsgálják, amelyek mind kialakulásukban, mind múködésükben, mind tevékenységi körükben eltérnek a hazai viszonyoktól. Véleményem szerint a magánbiztonságot mint partnert nem szabad ebben a változásban kifelejteni. Azt persze kijelenthetem, hogy a magánbiztonsági tevékenység nem rendészeti, mert a jogi háttere nem felel meg ennek a kritériumnak. A biztonsági őrök annyi jogosultsággal rendelkeznek, mint az átlag polgárok. Sem jogszabályi védelemben, sem legitim erőszak alkalmazásával nincsenek felruházva. Viszont, ha egy rendkívüli esemény történik, biztos, hogy van a helyszínen vagyonőr. Milyennek kell lennie az elvárásnak egy piaci alapon múködő biztonságot szolgáltató iparággal szemben. Csakis a képzés, az újfajta kihívásokra adható válaszok és eljárások, protokollok kidolgozása jelenthet megoldást. Magasan képzett, a helyzetet felismerő, specializált biztonsági szakemberekre van szükség. Az állami feladatok teljes kiszerveződése a magánpiacra nem igazán járható út. Nem lehet teljes mértékben ellenőrizni a magánbiztonságot, viszont a rendészeti szervezetek a tömeges bevándorlás okozta válsághelyzet miatt megnövekedett feladatai és a létszámhiány egyértelmúen alapozza meg a magánbiztonsággal egy

25 Wilson-Kelling (1982) 29-38. 
jövőbeni partnerség fejlesztését. A területi partnerségek megkötése és egy általános jogszabályi felhatalmazás megjelenése, mert a jövő, de már a jelen biztonsági kihívásait önmagában egy szervezet sem tudja megoldani. A tudománynak a kutatóknak is nagy szerepe van, a megfelelő ajánlások, szakpolitikák és protokollok kidolgozásában

A tanulmányban felvetett kérdésre az a határozott válasz, hogy a tömeges bevándorlás okozta válsághelyzet, a rendészeti szervezetek terheltsége elkerülhetetlenül jelenti, hogy a magánbiztonságra szükség van. A komplementer jelleg már eddig is jelen volt. Hiszen egy-egy területen, mint a turizmus vagy a rendezvénybiztosítás az állami rendészet nagyon jól használja a magánbiztonságot tehermentesítésre. Feladatot kell neki adni, nem szabad egy ilyen létszámú és komoly szakértelemmel, illetve felhalmozott tudással rendelkező szervezetrendszert ebben a fontos helyzetben kihasználatlanul hagyni. Összefoglalva, az állami rendészetnek és partnereinek így lehet komplementer rendészete a magánbiztonság, adott célból megfelelő ellenőrzés mellett meghatározott időszakokban törvényi felhatalmazással.

\section{IRODALOMJEGYZÉK}

Cseresnyés Ferenc (2004): A Magyar Köztársaság integrálása a szabadság, jog és a biztonság térségébe. A magyar határellenőrzés feladatai a közeljövőben Ausztria példája alapján. In Hautzinger Zoltán szerk.: Tanulmányok a „Magyar határellenőrzés - európai biztonság” címü tudományos konferenciáról; Pécsi Határör Tudományos Közlemények III. Pécs, Magyar Hadtudományi Társaság Határőr Szakosztály Pécsi Szakcsoportja. 43-52.

Finszter Géza (2013): A rendészet elmélete és a rendészeti eszközrendszer. Budapest, Nemzeti Közszolgálati Egyetem.

Garland, David (2003):The Risk of Risk. In Doyle, Aaron - Ericson, Aaron: Risk and Morality. Toronto, University of Toronto Press. 48-86. DOI: https://doi.org/10.3138/9781442679382-005

Giddens, Anthony (1990): The Consequences of Modernity. Polity Press, Cambridge. 71.

Giddens, Anthony (2000): Elszabadult világ. Hogyan alakakitja át életünket a globalizáció? Budapest, Perfekt Kiadó.

Gillespie, Wayne (2006): Capitalist World-Economy, Globalization and Violence. International Criminal Justice Review, Vol. 16. No. 1. 24-44. DOI: https://doi.org/10.1177/1057567705284480

Gönczöl Katalin - Kerezsi Klára - Korinek László - Lévay Miklós (2013): Kriminológia - Szakkriminológia. Budapest, Complex Kiadó.

Hautzinger Zoltán - Hegedûs Judit - Klenner Zoltán (2014): A migráció elmélete. Budapest Nemzeti Közszolgálati Egyetem.

Illés Sándor - Kincses Áron (2009): Migráció és cirkuláció. Statisztikai Szemle, 87. évf. 7-8. sz. 729-747.

Irk Ferenc (2012): Kétkedő kriminológia. A rizikótársadalom kriminálszociólógiája. Miskolc, Bíbor Kiadó.

Kacziba Antal (2013): Közrend, magánrend, közbiztonság. In Gál Gyula - Hautzinger Zoltán szerk.: Pécsi Határör Tudományos Közlemények. XIV. 23-36.

Koller Boglárka (2006): Nemzet, identitás és politika Európában. Budapest, L’Harmattan.

Orbán Balázs (2019): Bevándorlási válság. In Pásztor, Péter főszerk.: Magyar politikai enciklopédia. Budapest, Mathias Corvinus Collegium/Tihanyi Alapítvány. 13-18.

Wilson, James Q. - Kelling, George L. (1982): The police and neighborhood safety Broken Windows. Atlantic Monthly, Vol. 249. 29-38.

Windt Szandra (2008): Az illegális migráció kriminológiai jellemzôi. Miskolc, Miskolci Egyetem Államés Jogtudományi Kar Deák Ferenc Állam - és Jogtudományi Doktori Iskola. 


\section{Internetes források}

Bevándorlási és Menekültügyi Hivatal, Alapfogalmak. Forrás: www.bmbah.hu/index.php?option=com_k2\&view=item\&layout=item\&id=421\&Itemid=392\&lang=hu\# (2016. 11. 15.)

Pallas Nagylexikon. Forrás: http://mek.oszk.hu/00000/00060/html/013/pc001303.html\#7

(2016. 11. 15.)

www.valasztas.hu/ep2004/04/hu/informaciok/20_12.html (2016. 11. 15.)

http://unstats.un.org/unsd/demographic/sconcerns/migration/migrmethods.htm (2016. 11. 15.)

\section{Jogforrások}

Magyarország Alaptörvénye

41/2016. (III. 9.) Korm. rendelet a tömeges bevándorlás okozta válsághelyzet Magyarország egész területére történő elrendeléséről, valamint a válsághelyzet elrendelésével, fennállásával és megszüntetésével összefüggő szabályokról

2005. évi. CXXXIII: a személy- és vagyonvédelmi, valamint a magánnyomozói tevékenység szabályairól 2007. évi LXXX. törvény a menedékjogról

\section{ABSTRACT}

\section{Private Security Activity in the Context of the Crisis Caused by Mass Immigration}

SZABÓ László András

The title implies a situation of mass immigration caused by a crisis in which private security and the property security industry do not have a statutory duty. Refugees are not present in Hungary, as we saw in 2015. The future possibility of this state cannot be excluded. Public organisations are looking for partners due to the ongoing staff shortage resulting from border surveillance. In my study, I analyse the tasks of private security by dimensions, from the point of view of the crisis caused by mass immigration.

Keywords: private security, mass immigration, migration, dimensions, load 